INSTITUTE OF FORESTRY • BELGRADE

INSTITUT ZA ŠUMARSTVO • BEOGRAD

SUSTAINABLE FORESTRY

COLLECTION 69-70, 2014
ODRŽIVO ŠUMARSTVO

ZBORNIK RADOVA 69-70, 2014

UDK $630 * 273(497.11$ Obrenovac) $=111$

Original scientific paper

\title{
THE CONDITION OF AESCULUS HIPPOCASTANUM L. TREES IN THE AVENUES OF THE CENTRAL PART OF THE CITY OF OBRENOVAC
}

\author{
Milorad VESELINOVIĆl, Suzana MITROVIĆ ${ }^{\text {, Zlatan RADULOVIĆ }}$, $^{\text {, }}$ \\ Dragana DRAŽIĆ ${ }^{l}$, Nevena ČULE ${ }^{l}$, Dragica STANKOVIĆ ${ }^{2}$, Snežana RAJKOVIĆ ${ }^{1}$
}

\begin{abstract}
In urban areas treelined paths are the most vulnerable element. According expected functions treelined paths in certain street are unsatisfactory with their appearance and general condition. These are primarily biological, ecological, sociological and aesthetic functions. Because of negative anthropogenic influences trees are with low level condition, very low functionality and the unsatisfactory state of health. Most of the trees exist in very difficult circumstances of streets, there are crowded in the underground and in the aboveground part. In such circumstances, just as individual specimens of trees grow into individuals who manifest themselves in terms of morphology characteristics which are representative of its species. In this paper is presented the state of the avenue of horse chestnut (Aesculus hippocastanum L.) in two central streets of the old part of Obrenovca. The data were analyzed on the basis of the reviewed every tree and with the particular assessing the state of the crown and the state of the trunk. Based on the analysis of the results measures are proposed for the rehabilitation of individual trees as well as measures for the reconstruction of the entire tree line.
\end{abstract}

Key words: horse chestnut, treelined path, street, condition

\section{STANJE STABALA AESCULUS HIPPOCASTANUM L. U DRVOREDIMA CENTRALNOG DELA OBRENOVCA}

Izvod. U sistemu gradskog zelenila drvoredi su najugroženiji element. Drvoredi pojedinih ulica kod nas svojim izgledom i opštom kondicijom ne zadovoljavaju očekivane funkcije. To su u prvom redu biološke, ekološke, sociološke i estetske funkcije. Pod

\footnotetext{
${ }^{1}$ Institute of forestry, Belgrade, Serbia

Translation: Milorad Veselinović
} 
negativnim antropogenim uticajima stabla su niskog stepena kondicije, vrlo niske funkcionalnosti $i$ nezadovoljavajućeg zdravstvenog stanja. Većina stabla egzistira u vrlo teškim uslovima ulice, stešnjena su $i$ u podzemnom $i$ u nadzemnom delu. U takvim okolnostima samo pojedinačni primerci izrastu u individue koje u morfološkom smislu manifestuju reprezentativne osobine svoje vrste. U radu je prikazano stanje drvoreda divljeg kestena (Aesculus hippocastanum L.) u dve centralne ulice starog dela Obrenovca. Analizirani su podaci na osnovu pregledanog svakog stabla posebno ocenjivanjem stanja krune i stanja debla. Na osnovu anlize rezultata predložene su mere za sanaciju pojedinih stabala kao i mere za rekonstrukciju celokupnog drvoreda.

Ključne reči: divlji kesten, drvored, ulica, kondicija biljaka.

\section{INTRODUCTION}

Rows of trees represent a narrow belt of greenery, which is commonly known as the green line. Treeline paths are one of the most important categories of greenery in urban areas. Functions of avenue tree plants are primarily environmental, commonly branded as sanitary. Fulfilment of these functions is in accordance with the number of plants, quantity and physiological status of the foliage. The second group of functions compiled all the other functions which can be regarded as an indirect function, often defined as aesthetic, psychological or cultural. Their actual fulfilment of the primary and secondary functions is possible only under the condition that the individual tree rows are in excellent or at least very good health and an acceptable aesthetic status (Dobrilovič, 2009). Only healthy plant organisms those individuals whose life functions smoothly and completely performed can fulfil the expected functions (Bunuševac, 1977). The increasingly difficult for rows of trees will be to survive in a form that residents traditionally considered tree-lined (Batala and Tsitsoni, 2007). Most of the trees exist in very difficult conditions of the streets. Most of them squeezed in the underground as well as the above ground part by the human action. There are the rare opportunities that trees as individual specimens in the rows of tree grow into individuals who manifest themselves in terms of morphology characteristics representative of its species.

Ecological very difficult environmental conditions on the streets are reasons why the alley of trees having great ecological importance, but also why this specific category of public greenery adorned with the epithet "the most important secondary element of streets in major cities" (Mumford, 1988). Ttreelined paths, especially those old and luxurious, composed of individuals spanning many decades, rarely to be encountered on the streets of major cities. Where alleys are held as a structural element of the street, they are existing mostly as very young plants. Today for the trees is planning a much shorter time for functioning and existence on the street it is about two to three decades. After this period all of the tree rows tree as a rule will be removed. After that time trees will be replace with the new, young, healthy individuals, by size more directly proper with the available space on the street. Such trees will also be much easier to nurture. So in the future the trees of tree lined paths on the streets of cities will be considered as structure that needs to be constantly improved. Horse chestnut the tertiary relict of the Balkan Peninsula is 
very frequently used species at alleys in our cities (Ćalić-Dragosavac et al., 2009). Cadastre of the trees and shrubs at public green space of the metropolitan area of the Obrenovac indicates that this species is very common in the street alleys of the city.

\section{MATERIAL AND METHOD}

Inventory of the horse chestnut trees in two central streets in Obrenovac was performed by measuring individual trees. Diameters of the trunk at breast height were measured by caliper. The total height of the tree, trunk height to the beginning of the crown, height and crown width were measured by laser rangefinder-hypsometer TruPulse $360 \mathrm{~B}$. Based on the obtained data the analyses of certain parameters were made in relation to the most distribution of trees per diameter class.

In the same time the presence of fruiting bodies of fungi and the presence of insect damage were registered. In the cases when the exact cause of the damage couldn't determine on the ground, in the laboratory were identified using standard phytopathological methods and using appropriate keys: B.C. Suttona (The Coleomycetes, 1980), J.V. Carmichaela et al. (Genera of Hyphomycetes, 1980), R.W.G. Dennisa (British Ascomycetes, 1978), J.A. Arxa (Genera of Fungi Sporulating in pure Culture, 1974), V.H. Kuprevicha i V.G. Tranchela (Rust Fungi, 1970).

\section{RESULTS AND DISCUSSION}

\subsection{Morphometric characteristics of trees}

Within the area of public character of the urban area of the Obrenovac horse chestnut was registered 338 times. From that number 96 trees are registered in different green areas categories, and 242 trees in the tree lined path. At the Vuk Karadzić street is located 204 trees and at the Karađorđeva street 34 trees, which represents $98.35 \%$ of the total number of horse chestnut trees in strips.

Table 1. Distribution of trees per diameter class

\begin{tabular}{|l|l|l|l|l|l|l|l|}
\hline \multirow{2}{*}{ Street } & \multicolumn{6}{|c|}{ Number of the trees distributed per diameter class } & \multirow{2}{*}{ Total } \\
\cline { 2 - 7 } & $1-10$ & $11-20$ & $21-30$ & $31-40$ & $41-50$ & $51-60$ & \\
\hline Vuka Karadžića & 23 & 13 & 64 & 85 & 17 & 2 & 204 \\
\hline Karađorđeva & 1 & 1 & 8 & 17 & 5 & 2 & 34 \\
\hline
\end{tabular}

The most common diameter classe in both analyzed streets is class 21-30 (3) with a share of $30.39 \%$ at Vuk Karadzić and $26.47 \%$ in Karađorđeva street. Diameter class of 31-40 (4) with a share of $43.14 \%$ at Vuk Karadzić and $47.06 \%$ in Karađorđeva street. Diameter class of 41-50 (5) with a share of $7.84 \%$ at Vuk Karadzic and $17.65 \%$ in Karađorđevoj street. Total analyzed trees at Vuk Karadzic were 166 which amount to $81.37 \%$ of the trees of the street and 31 trees at the Karađorđeva street or $91.18 \%$ of the trees at the street (Table 1). 
Analysis of measured data indicates that in most frequent diameter classes 4 and 5 in both analyzed streets weren't statistically significant differences in the amount of trees, trunk length, height and width of the crown (Table 2). This can be explained by anthropogenic influence when the trees were subjected to various treatments (artificial lifting the crown, the crown pruning, etc.) to adjust their size to the available space of the street and infrastructure objects in it. Compared to them there is a statistical difference for the analyzed parameter in the diameter class of 3 because the trees in this class with their habitus fit in the available space on the streets.

Table 2. The dependence of morphometric parameters in relation to the diameter increment

\begin{tabular}{|c|c|c|c|c|c|}
\hline Street & $\begin{array}{l}\text { Diameter } \\
\text { increment }\end{array}$ & $\begin{array}{l}\text { Total height of the } \\
\text { tree }\end{array}$ & Trunk height & Crown height & Crown width \\
\hline \multirow{3}{*}{$\begin{array}{l}\text { Vuka } \\
\text { Karadžića }\end{array}$} & 3 & $12.5938 \pm 1.4787^{\mathrm{a}}$ & $2.5500 \pm 0.7177^{\mathrm{a}}$ & $6.3333 \pm 1.1764^{\mathrm{a}}$ & $9.5125 \pm 1.6320^{\mathrm{a}}$ \\
\hline & 4 & $12.7222 \pm 1.8704^{\mathrm{a}}$ & $3.0813 \pm 0.9078^{\mathrm{a}}$ & $6.8438 \pm 1.4880^{\mathrm{a}}$ & $9.5889 \pm 2.0643^{\mathrm{a}}$ \\
\hline & 5 & $13.7500 \pm 1.6989^{\mathrm{a}}$ & $3.1333 \pm 0.8246^{\mathrm{a}}$ & $\begin{array}{lll}8.6667 & \pm & 1 . \\
3516 b^{\mathrm{a}} & & \\
\end{array}$ & $\begin{array}{l}11.2000 \pm 1 . \\
8750^{\mathrm{a}}\end{array}$ \\
\hline \multirow{3}{*}{ Karađorđeva } & 3 & $9.3952 \pm 0.4536^{\mathrm{a}}$ & $2.5048 \pm 0.1666^{\mathrm{a}}$ & $6.1452 \pm 0.3663^{\mathrm{a}}$ & $6.8903 \pm 0.4560^{\mathrm{a}}$ \\
\hline & 4 & $11.7932 \pm 0.76711^{b}$ & $2.6591 \pm 0.2817^{\mathrm{ab}}$ & $7.3500 \pm 0.6194^{b}$ & $9.1341 \pm 0.7712^{b}$ \\
\hline & 5 & $12.4688 \pm 0.7435^{\mathrm{b}}$ & $2.8188 \pm 0.2730^{\mathrm{b}}$ & $7.8438 \pm 0.6003^{b}$ & $9.6500 \pm 0.7475^{\mathrm{b}}$ \\
\hline
\end{tabular}

a - multiple interval test - the values marked by the same letter in the column, does not indicate a difference on the level of significance $\mathrm{p}<0.05$.

\subsection{Health condition}

\section{Phytopathological disease}

Guignardia aesculi (Peck.) Stew. - Horse chestnut Leaf Blotch. This is the accompanying disease of horse chestnut, which was established in Europe in 1950. It also occurs on the A. glabra, A. pavia as well as on the Aesculus x carnea (hibrid A.hippocastanum x Aesculus pavia). Kao posledica napada dolazi do ranog opadanja lista što izaziva smanjenje dekorativnosti, a takođe dolazi i do napada sekundarnih parazita i štetočina. As a result of the attack leads is the earlier falling of the leaves which causes a reduce decoration of the trees but also leads to the attacks of secondary pests and parasites. The disease is present on the leaves of mature trees wherein the disturbs the aesthetic appearance of the trees (especially in parks and alleys). Recommended sction against this disease is collection and removal of leaves as a source of infectious inoculum. The disease was detected in all analyzed trees.

Uncinula fraxini Miyake. - Horse Chestnut Powdery Mildew. Beside ash tree the disease occurs also at the horse chestnut. As all powdery mildew this species also is an obligate parasite and can only be developed on living plants. This species is the only one horse chestnut tree, and the attack was weak.

\section{Wood decay fungi}

Inonotus hispidus (Bull. ex Fr.) Karst. This species is being developed as a parasite weakness in hardwoods. I.hispidus develops as a parasite on live trees and causes white-yellow central decay of trunk. Infections achieved through injury on trunk and branches. When trees are infected with this fungus the fractures and 
breakage of branches in the crown are very common. It is registered at more than $50 \%$ of the analized trees

Ganoderma applanatum (Pers, ex Wallr.) Pat. syn. Fomes applanatus (Pers.) Wallr. It occurs in lots of hardwoods. At live trees usually attacks the terrestrial part of the stem and roots which causes white-yellow decay of heartwood and partly sapwood Due to the destruction of the heartwood and sapwood the tree loses its firmness and has been frequently damaged by winds. Infection of trees and root occurs through their injuries It is registered at more than $15 \%$ of the analyzed trees.

Schizophyllum commune Fr. This fungus is one of most widespread species. On live trees is located on damaged and dead parts causing peripheral white sapwood decay. The destructive activity of the fungi is relatively small so that it retains the decay in the surface layers of wood. It is registered in over $25 \%$ of the analized trees.

Trametes hirsuta (Wulf.:Fr.) Pil. It causes perforated white decay. It occurs as a saprophyte in parts of the sapwood live trees which are necrose due to adverse effects of various factorsExtremely can cause soft decay of heartwood of some species. It's common on the analized trees in the avenues.

Phytophthora spp. On the analized trees of horse chestnut in Obrenovac was registrated the presence of three species of the genus Phytophthora as follows: Phytophthora cambivora (Petri) Buisman, Phytophthora cactorum (Lebert \& Cohn) J. Schröt. and Phytophthora citricola Sawada. They cause root decay and cause bark shoot, dries and falls over large areas on the tree. This may prevent the normal flow of mineral matter which is manifested by drying of individual branches in the crown and wilted of leaves. They appear very often,even on the 48 of the analyzed horse chestnuts in Obrenovac were determined symptoms ("Bleeding canker") that indicate their presence.

\section{Insects}

The registered insects occur in very low intensity at the analized trees in the avenues.

Cameraria ochridella Deschka and Dimić- Horse Chestnut Leaf Miner. The first time it was discovered in 1984 in the vicinity of Ohrid in Macedonia on the basis of characteristic mines on the leaves of the horse chestnut (Aesculus hippocastanum L.) (Simova-Tošić and Filev, 1985). Shortly after that miner is rapidly spreading to the north and occupies the the whole territory of Serbia (Dimic and Mihajlovic, 1993). At a stronger attack leaves are dried and falling. Populations of horse chestnut leaf miner are numerous. Stabla divljeg kestena već u avgustu ostaju bez lišća, a u septembru i oktobru ponovo listaju i cvetaju, što je svojevrsni stres. Horse chestnut trees already in august lose their leaves and in september and october gets leaves and flowers again, which is sign of some kind of stress.

Pulvinaria betulae (L.) - Cottony grape scale. The species is occur on a large number of plant species. It does not cause significant damage.

Parthenolecanium corni (Bouche) - European fruit lecanium. Occurs in more than 350 plant species. It occurs in gradations and primarily attacks the young 
plants. In the years of outbreak causes drying of individual branches and after several consecutive years can lead to drying of whole trees.

\section{CONCLUSIONS}

Modern European cities nearly 350 years persistently trying to establish and maintain mature individual tree in the functional state at the streets (Harris, et al.1999). Sve češće se zapaža da je i tamo gde se drvoredi još uvek uporno održavaju kao strukturni elemenat ulice, reč uglavnom o vrlo mladim biljkama. Usually where the rows of trees still persistently held as a structural element of the streets it's refers to young plants. In order to maintain their functionality for those trees are planning a much shorter period of existence on the streets. This is illustrated by the results of our research where plants that come under intense anthropogenic impact to keep them in the allowed space are losing their natural habitat characteristics. With invasive measures correcting the size and shape of the crown they lose leaf mass and become susceptible to various diseases and pests. As the functioning of trees intimately associated with morphological, biological and ecological characteristics, it can be certainly to conclude that there is no "natural use" of trees on the street will not be if it comprised the sick, broken and damaged plants. A large number of horse chestnut trees in a small space and the closeness and connection in a tree line allows for easy transmission of the disease and insects from tree to tree. This is supported by the negative influence of abiotic factors and the resistance of plants in the alleys is considerably reduced.

Because of that the trees in the form of a row of trees should be considered as a structure that needs to be constantly improved. For this purpose it can be recommended measures of successive replacement of horse chestnut trees with another species of trees in entire streets of the city of Obrenovac. This would reduce the risk of occurrence of these diseases and pests on the individual horse chestnut trees in surround greenery.

\section{ACKNOWLEDGEMENTS}

The research was partly financed by the Ministry of Education and Science, Republic of Serbia, within the Project „The study of climate change on the environment: monitoring impacts, adaption and mitigation "III 43007.

\section{REFERENCES}

Batala E. and Tsitsoni T. (2007): Research on urban greenery of representative types in the avenues of a big city. Proceedings of the International Conference on Environmental Management, Engineering, Planning and Economics. Skiathos, June 24-28, : 2979-2984

Bunuševac, T. (1977): Uloga zelenih površina u melioraciji nepovoljnih uslova sredine naselja Srbije. Glasnik Šumarskog fakulteta, serija C - Pejzažna arhitektura, 51: 9-34.

CAB- Commonwealth Mycological Institute, Kew, Surrey, England (696p.) 
Carmichael JW, Kendrick WB, Conners IL, Sigler L. 1980. Genera of Hyphomycetes. Alberta, Canada: University of Alberta Press. 386 p.

Ćilić-Dragosavac D., Zdravković-Korać S., Milinković D., Radoiević L. 2009. Comparative analysis of microscope size variability in the genus Aesculus (Hippocastanaceae). Arch. Biol. Sci. Belgrade, 61 (4): 795-800

Dennis, R.W.G. (1978) British Ascomycetes. Vaduz: J.Cramer

Dimić, N., Mihajlović, Lj. (1993): Širenje areala minera divljeg kestena Cameraria ohridella Deschka \& Dimić (Lepidoptera, Lithocolletidae) i njegovi prirodni neprijatelji. Zbornik rezimea XXI skupa entomologa Jugoslavije, p. 33. Beograd.

Dobrilovič M. (2009): Urban tree avenues - morphological characteristics as a factor in trees selection. Agronomski glasnik, No 2/2009: 111-126

Harris, R. W., Clarc, J. R. and Matheny, N. P. (1999): Arboriculture, Integrated management of landscape trees, shrubs and vines. Prentice Hall, New Jersey.

Kuprevich, F.V., Tranchel, V.G. (1970) Rust fungi. Moskva-Leningrad: Akademija nauk SSSR - Botanički institut

Mumford, L. (1988): Grad u historiji - njegov postanak, njegovo mijenjanje, njegovi izgledi. Naprijed, Zagreb

Simova-Tošić, D., Filev, S. (1985): Prilog poznavanju minera divljeg kestena. Zaätita Bilja 36 (3): 173. Beograd.

Sutton, B. C. (1980): The Coleomycetes. Fungi Imperfecti with Pycnidia Acervuli and Stromata.

Von Arx JA (1974) The Genera of fungi sporulating in pure culture. 2 ed. J. Cramer, Vaduz, Germany. 351 pp. 